DOI: https://doi.org/10.47405/mjssh.v6i8.965

\begin{tabular}{|c|c|}
\hline 4 & Malaysian Journal of Social Sciences and Humanities (MJSSH) \\
\hline $\begin{array}{l}\text { Malaysian Juoural of } \\
\text { Social ccciecces and }\end{array}$ & Volume 6, Issue 8, August 2021 \\
\hline (MJ-sSH) & e-ISSN : 2504-8562 \\
\hline & $\begin{array}{l}\text { Journal home page: } \\
\text { www.msocialsciences.com }\end{array}$ \\
\hline
\end{tabular}

\title{
An Examination of The Relationship of Green Brand Affect and Other Determinant Factors Towards Green Purchase Intention in Skin Care Industry
}

\author{
Alya Salsabil Ryliannabila ${ }^{1}$, Annisa Rahmani Qastarin ${ }^{1}$ \\ ${ }^{1}$ School of Business and Management, Bandung Institute of Technology, Indonesia \\ Correspondence: Alya Salsabil Ryliannabila (alya_salsabil@sbm-itb.ac.id)
}

\begin{abstract}
Climate change is a troubling issue in the world and one of the main causes is plastic production, while the personal care industry is one of the industries that contributes the largest plastic waste and businesses in Indonesia have not contributed to reducing waste. According to a study, many small businesses face several challenges in implementing environmental values including unawareness of the potential presented by applicable green practices, a lack of understanding of the necessity to address their environmental consequences, and the lack of understanding how to integrate green practices into basic business planning, in other words they don't little exposure to green practice information and they don't know how to communicate \& implement the environmental values, thus small businesses need to understand how to communicate their business through green brand and to communicate their brand business need to know what drives the customer to buy green brand. While "green purchase intentions" is the likelihood of consumers purchasing specific products or brands owing to environmental concerns, thus to support waste reduction from the personal care industry and increase implementation of environmental value, the researcher analysed what factors could influence green purchase intentions to understand the market needs and drivers to purchase green brands. Using the PLS SEM, this study investigates the relationship of green brand affect on green purchase intentions, as well as the mediation effects of green brand attitude and green brand associations in the skin care business. Refers to prior study to define 'green brand affect' as "consumers' positive emotional response towards a brand in consequence of the brand's environmental performance" because in the process of customer buying decision-making, brand affect is a critical aspect. The study's research focus is on Indonesian consumers aged 14 to 39 who have purchased green skin care brands in Indonesia. A total of 218 respondents were chosen. In addition, to verify the research framework, this study was done by utilizing a questionnaire survey. The findings show that the impact of a green brand can have a direct impact on green buying intentions. Furthermore, this research shows that green brand associations have no influence on green purchasing intention means this variable fails to mediating green brand affect toward green purchase intention and that green brand attitude mediates the relationship between green brand affect and green buy intents to partially. While businesses tend to enhance their customers' green purchase intentions, they must also increase their green brand impact and green brand attitude. Hopefully this research could help small businesses to understand how to communicate and implement environmental value through the understanding of the relationship between green brand affect, green brand attitude, and green brand association toward green purchase intention.
\end{abstract}

Keywords: green branding, brand affect, brand association, brand attitude, green purchase intention 


\section{Introduction}

Based on data that is recorded by National Oceanic and Atmospheric Administration (NOAA), since $1960 \mathrm{~s}$, the global temperature has been raised as much as 0.82 Celsius degree higher than the average temperature in the 20th century and overall the year 2020 and 2016 has been the hottest years with temperature 1.2 Celsius degree higher than temperate average of 19th century (Roston, 2021). Recorded until February 9, 2021, National Board for Disaster Management (BNPB) said that the compiled data shows there are already 386 natural disasters happened in Indonesia dominated by flood with 232 cases, followed by tornado with 73 cases and landslide with 62 cases (Ayomi \& Aghnia, 2021), $98 \%$ of those disasters are caused by hydrometeorology factors which is most likely happened because of the effect of climate change. (Dewi, 2021).

Climate change is caused by greenhouse gasses such as carbon dioxide, methane, nitrous oxide, etc. About $64 \%$ of carbon dioxide, one of greenhouse gasses, is produced from human activities that cause global warming (Europa, 2020). One of the greatest producers of greenhouse gases is the activity of producing plastics. Other than that, one-time-use plastic is also causing damage to the earth since it's not degradable. In 2019 the activity of plastic production alone contributed up to 850 million tons of greenhouse gases and is predicted to reach 2.8 billion tons in 2050 other than that around 8 million plastic waste are being dumped to the ocean each year that can directly kill marine animals and endangered the ecosystem (WWF, 2019). An even sadder fact is that Indonesia is the largest waste producer in ASEAN with producing 67.8 million tons of waste based on the Ministry of Environment and Forestry and also the second largest plastic waste producing country in the world after China. In one year, Indonesia contributed 1.3 million tons of plastic waste to the oceans, this was conveyed by the Head of the DKI Jakarta Environment Agency, Andono Warih.

Moreover, based on preliminary research done to approximately 60 The Daily Maiimi's social media audience data shows that $92 \%$ of respondents said that they're more likely to be interested in buying products that offers eco-friendly values and $98 \%$ of them are aware of climate change but this contradict with data of environmental issues that shows $51 \%$ businesses in Indonesia, Malaysia, Philippines, Thailand and Vietnam still not contributing in reducing plastic waste yet (UNEP, 2020) Environmental problems have become an emergency and should be worried about, but there are still many business owners who have not implemented environmentally friendly values, this study aims to analyze the use of and green marketing by SMEs and how this affects purchase intention in Indonesia to fill in the gap. To support, $85 \%$ respondents also show their willingness to pay more effort and cost to have more environmentally responsible products.

Unfortunately, based on data from UN Environment Program that shows 51\% businesses in Indonesia, Malaysia, Philippines, Thailand and Vietnam are still not contributing to reducing plastic waste yet (UNEP, 2020). Especially for personal care products that refer to Based Health Europe 2019 have been reported to produce more trash than we had anticipated due to rising demand, even more, one of the primary sources of water pollution is personal care products. Refer to Statista (2015), the Indonesian beauty and personal care product industry is vast and rising, with revenues expected to reach $\$ 7.5$ billion in 2021 and grow at a 6.5 percent compound annual growth rate through 2025 . Personal care has the largest market category ( $\$ 3.2$ billion), followed by skin care ( $\$ 2.1$ billion), cosmetics ( $\$ 1.7$ billion), and perfumes ( $\$ 0.4$ billion). According to a study, many small business regard the environment as a "peripheral" rather than a "fundamental" business concern, and therefore do not believe they have a substantial environmental effect (Peters and Turner, 2004; Redmond, Walker and Wang, 2008). This is a serious issue as it indicates that small businesses are not yet engaged in the environmental debate, it's possible that small businesses are unaware of their importance in the environmental agenda as Madden \& Scaife (2009) found that small businesses "generally believed they lacked an overall vision or purpose for their community involvement and what it could achieve for their business". Due to this condition, education would be the vital change to this regard. 
According to OECD (2015), small businesses have significant challenges when it comes to adopting environmental management systems (EMSs), including a lack of resources, expertise, and technical competence, high initial expenditures, and poor public awareness. In detailed here some of the consideration of small business in implementing environmental values based on OECD (2015).

And according to Chen et al., (2020), positioning of green branding strategies is to establish a unique sustainable image among the targeted customers, in order to achieve their green claims, due to the increasing recognition and understanding of environmentalism in the market, thus by using branding to understand how to communicate the environmental value and optimizing opportunity. Laura Lake (2021) said that a good brand is the one that motivates buyers to make a purchase by emotionally connecting target prospects with a product or service. Based on previous research by Matzler, et al. (2006), in the process of customer buying decision-making, brand affect is a key aspect. And in the sustainable era, the biggest issue for businesses is to improve green purchase intentions (Chen et al., 2020).

\section{Literature Review}

\section{Green Brand Affect}

Referring to Chaudhuri and Holbrook (2001), green brand affect is defined as "Consumers' positive emotional response towards a brand in consequence of the brand's environmental performance". Previous study has found that 'brand affect' has a significant impact on customer behavior and purchase decisions, demonstrating that emotion may be used as a primary predictor of consumer behavior (Erevelles, 1998).

\section{Green Brand Association}

Consumer knowledge linked with a particular brand is referred to as "brand association," which is a key component of brand equity (Aaker, 1991). Brand associations can be characterized by three aspects: strength, favorability, and uniqueness (Chen, et al., 2020). Green brand association is a vital form of consumer-based brand equity that adds significant value to a green brand by assisting in the processing and retrieval of information, establishing good attitudes and feelings, and providing a cause to buy (Zhang, 2010).

\section{Green Brand Affect on Green Brand Association}

The amount to which customers are aware of green brands, as well as how they feel about and judge them, is referred to as 'green brand associations' (Chen and Chang, 2012). Green brands can be associated with a customer's emotion to elicit a good response to the brand once the target customer has used it. Consumers will have greater purchasing behaviors for a brand that can make them feel happy, excited, or cheerful, as well as a higher loyalty attitude (Chaudhuri and Holbrook, 2001). According to previous research, brand affect can be utilized as the primary predictor of consumer behavior (Erevelles, 1998)

\section{Green Brand Attitude}

A consumer's automatic affective response to a product, or one's subjective feeling for the overall brand, is referred to as brand attitude (Eagle and Chaiken, 1995). According to Chen, et al. (2017), "green brand attitude" refers to customers' attitudes toward a brand's overall green performance, or in other words, "green brand attitude" refers to a consumer's eco attitude, which leads to one's overall evaluation of a green brand. 


\section{Green Brand Affect on Green Brand Attitude}

The degree of consumer adoration for a particular brand is referred to as brand affect (Chen et al., 2020). Brand emotional attachment is an effective method for brands to connect with people (Gobe, 2009). To sustain a long-term competitive advantage in the market, businesses must engage with customers on an emotional level and create fantastic feelings for them (Pawle and Cooper, 2006). Consumers' attitudes on their overall appraisal of a brand's green performance are referred to as "green brand attitude" (Chen et al., 2017).

\section{Green Purchase Intention}

According to Chen and Chang (2012), the likelihood of consumers purchasing specific products or brands owing to environmental concerns is known as "green purchase intentions". Furthermore, this work uses Chang and Chen (2008) to measure green purchase intentions, which consists of three components:
i. You want to buy this product because it is environmentally friendly.
ii. Because of its environmental performance, you expect to purchase this product in the future.
iii. In general, you are pleased with your purchase because it is environmentally beneficial.

\section{Green Brand Affect on Green Purchase Intention}

In the process of customer buying decision-making, brand affect is a critical aspect. Green product buying decisions will be influenced by consumers' perceptions and attitudes (Mostafa, 2006). Consumers are most prone to disregard product facts in favor of the brand that they believe is the most positive (Chaudhuri and Holbrook, 2001). The idea of customers purchasing certain products or brands based on their environmental needs is known as "green purchase intentions" (Chen and Chang, 2012).

\section{Green Brand Association on Green Brand Attitude}

Receiver fancies and memories elicited by stimuli are referred to as associations (Praxmarer and Gierl, 2009). Positive thoughts have a positive impact on the formation of a positive brand attitude, whereas negative thoughts have the opposite effect (Olson, et al., 1982). Feelings and emotional responses can be evoked by brand associations (Sujan, et al., 1993; Schindler and Holbrook, 2003; Escalas, 2004).

\section{Green Brand Association on Green Purchase Intention}

Brand associations are memories associated with a brand based on a consumer's frequent interactions with that brand (McWilliam, 1993). As a result, the brand association stored in the consumer's mind has the potential to alter the brand's image (Keller and Aaker, 1990). In conclusion, through expressing brand credibility and, more importantly, creating the brand's reputation, brand associations can impact consumers' purchase decisions (Chen et al., 2020).

\section{Green Brand Attitude on Green Purchase Intention}

A person's internal persistent evaluation of an object, situation, person, brand, product, or action is described as their attitude (Hoyer and Maclnnis, 1997; Sallam and Wahid, 2012). Benefits are the consumers' perceived values attached to the brand qualities, whereas brand attitudes are the consumers' overall assessment of the brand (Chen et al., 2020). Previous study has demonstrated that attitudes play a significant role in determining consumers' purchasing intentions (Yi, 1990; Goldsmith, et al., 2000). 


\section{Conceptual Framework and Hypotheses}

The framework and variables were derived from Chen, et al. (2020) about the structural equation model used to investigate the mediation effects of green brand attitude and green brand associations on green purchasing intentions and the influence of green brand affect on green purchase intentions.

Figure 1: Conceptual Framework

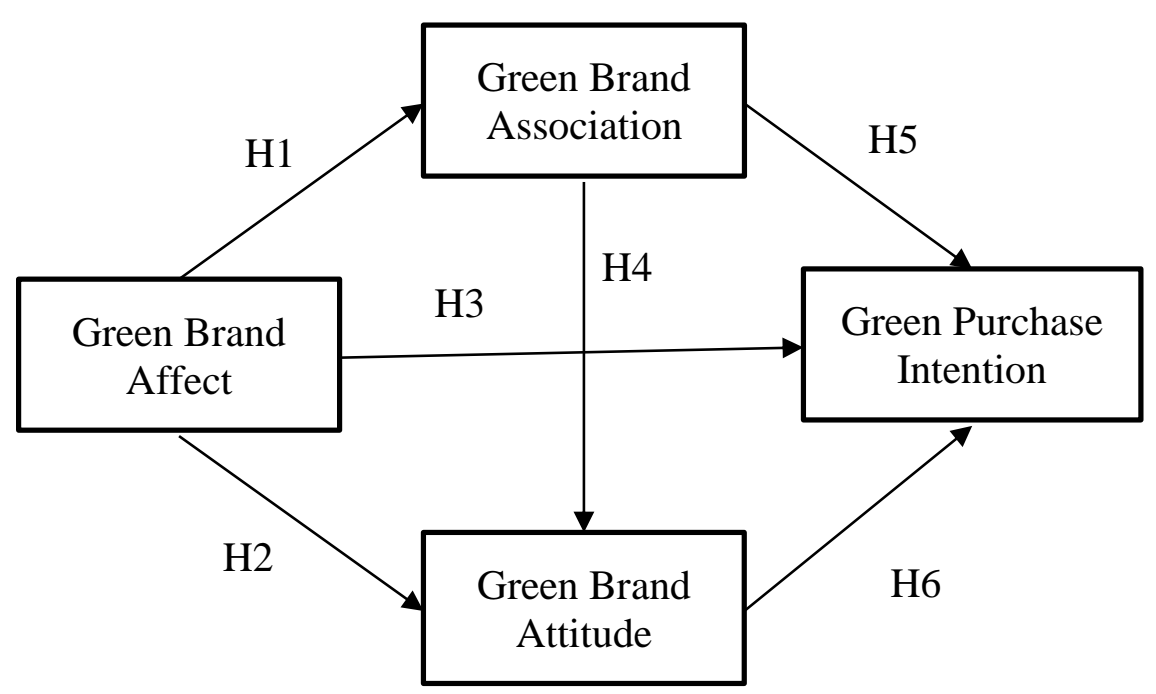

The following are a series of hypotheses that represent the relationship:

H1 : Green Brand Affect positively influences Green Brand Association

$\mathrm{H} 2$ : Green Brand Affect positively influences Green Brand Attitude

H3 : Green Brand Affect positively influences Green Purchase Intention

H4 : Green Brand Association positively influences Green Brand Attitude

H5 : Green Brand Association positively influences Green Purchase Intention

H6 : Green Brand Attitude positively influences Green Purchase Intention

\section{Methodology}

\section{Research Design}

Then researchers determine the problem statement based on the data gathered on research background. To test hypotheses, the researcher uses an online questionnaire to collect all data in a quantitative manner. Finally, by studying how green brand affect influences green purchasing intention, the findings of this study will bring new information and ideas for firms in the Indonesian beauty and personal care market.

\section{Population}

This research target population are customers that have been purchasing skin care brands that implement environmental values who live in Indonesia. The chosen sample ranges from 13 - 38 years old, considering the reference from ZAP Beauty Index 2020 that shows Gen Z (13 - 22) and Gen Y (23 - 38) spends the most money on beauty needs. Sample size indicates the number of items that will be used in the study. 


\section{Sampling Procedures}

Non-probability sampling is used in this study. Non-probability sampling is a technique for obtaining samples that does not offer equal opportunities to all participants or units within the population (Etikan, 2016). Purposive sampling was chosen because the researcher decides what needs to be learned and chooses people who can and will provide the information based on their knowledge or experience (BERNARD, 2006).

\section{Data Collection}

Table 1 explains the questionnaire's operational variable in greater detail. It specifies the variables or constructs of the questionnaire, as well as the item or question for the questionnaire. Referring to the previous journal, all items were rated on a seven-point Likert scale ranging from one (strongly disagree) to seven (strongly agree). According to Sauro (2010), seven points of likert type is a decent compromise between earning enough discrimination points and not having to preserve too many response options.

Table 1: Research Measurement and Variables

\begin{tabular}{|c|c|c|c|c|}
\hline \multirow{2}{*}{ No } & \multirow{2}{*}{ Variable } & \multicolumn{2}{|l|}{ Items } & \multirow{2}{*}{ Resources } \\
\hline & & Labels & Contents & \\
\hline \multirow[t]{3}{*}{1} & Green Brand Affect & GB1 & $\begin{array}{l}\text { The environmental friendliness } \\
\text { of skin care brands makes you } \\
\text { feel good. }\end{array}$ & \multirow{3}{*}{$\begin{array}{l}\text { Chaudhuri and } \\
\text { Holbrook, } 2001\end{array}$} \\
\hline & & GB2 & $\begin{array}{l}\text { The skin care brand's emphasis } \\
\text { on environmental protection } \\
\text { makes you feel good. }\end{array}$ & \\
\hline & & GB3 & $\begin{array}{l}\text { The skin care brand's } \\
\text { environmental performance } \\
\text { makes you happy. }\end{array}$ & \\
\hline \multirow[t]{3}{*}{2} & Green Brand Association & GAS1 & $\begin{array}{l}\text { The strength of the skin care } \\
\text { brand's environmental features } \\
\text { is outstanding. }\end{array}$ & \multirow{3}{*}{$\begin{array}{l}\text { Chen and Chang } \\
2016\end{array}$} \\
\hline & & GAS2 & $\begin{array}{l}\text { The favorability of the skin } \\
\text { care brand's environmental } \\
\text { features is better than that of } \\
\text { other brands. }\end{array}$ & \\
\hline & & GAS3 & $\begin{array}{l}\text { The uniqueness of the skin care } \\
\text { brand's environmental features } \\
\text { is excellent. }\end{array}$ & \\
\hline \multirow[t]{2}{*}{3} & Green Brand Attitude & GAT1 & $\begin{array}{l}\text { You will like this skin care } \\
\text { brand more because the brand } \\
\text { is environmentally friendly. }\end{array}$ & \multirow[b]{2}{*}{ Chen et al., 2017} \\
\hline & & GAT2 & $\begin{array}{l}\text { You will prefer the skin care } \\
\text { brand because of your concern }\end{array}$ & \\
\hline
\end{tabular}




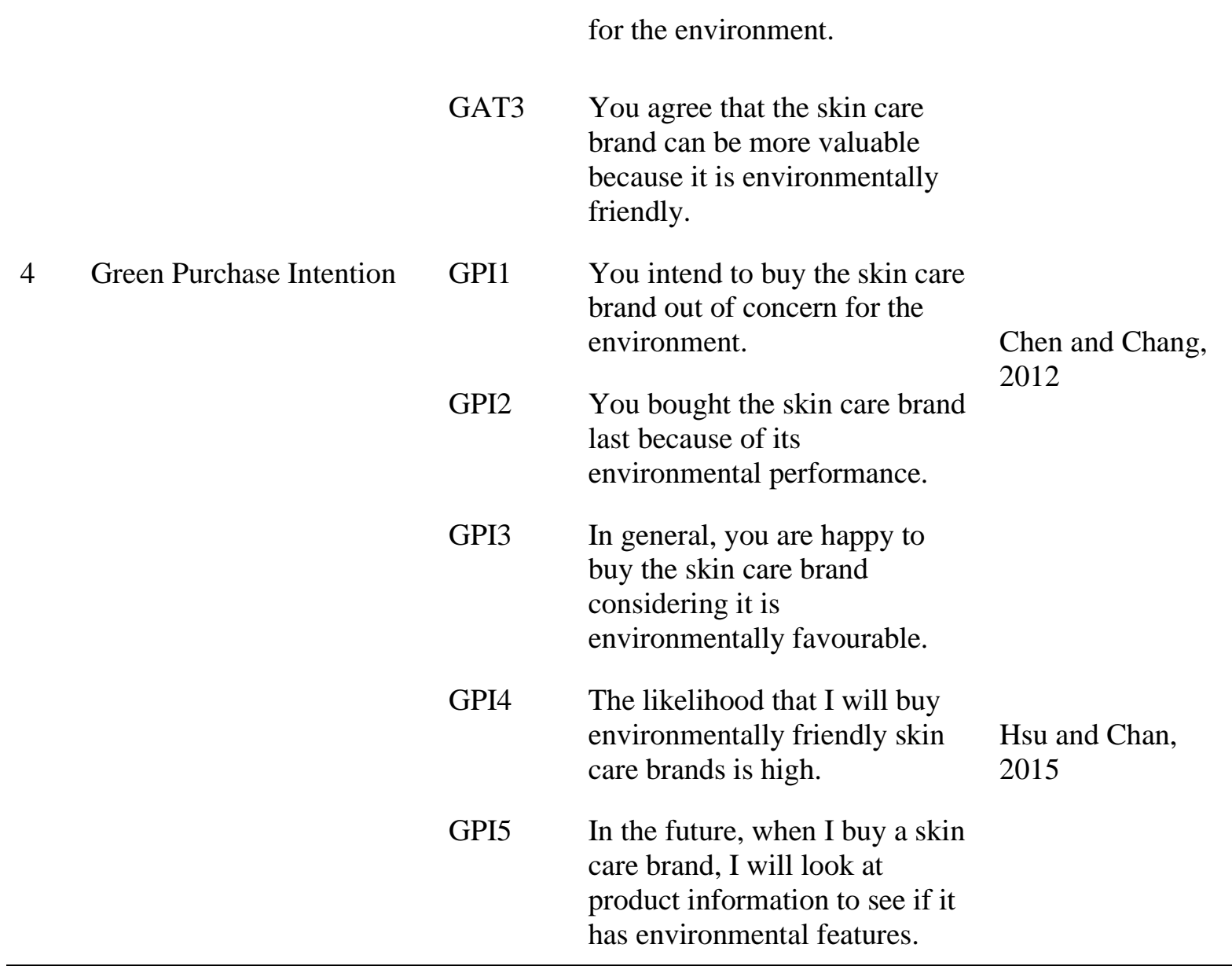

\section{Data Analysis}

To process data from this research, the researcher will use Partial Least Squares (PLS). PLS is a structural equation model technique that aims to optimize the explained variance of endogenous components (Fornell \& Bookstein, 2012). PLS-SEM is more like multiple regression than Covariance Based-SEM, which is used to confirm theories by determining how well a model can assess the sample data's covariance matrix, PLS-SEM is appropriate for this exploratory research because of these qualities because this is designed for research that is both data-rich and theory-skeletal (Hair et al., 2011). The application of empirical methods in business applications has two goals: prediction and explanation (Sarstedt et al., 2014). To test PLS-SEM, SMART PLS is used as the analytics program and the primary approach for evaluating the data acquired in order to uncover fresh insights about the research topic. SMART PLS is used to examine the questionnaire's measurement model, structural model, and intervening (mediation).

\section{Result}

\section{Convergent Validity}

Factor loadings, or the correlation coefficient for the variable and factor, can be used to verify convergent validity. A factor loading of 0.7 or higher in the SEM approach implies that the factor reduces adequate variance from the variable. According to Malhotra (2016), the Average Variance Extracted (AVE) must be at least 0.5 to pass the convergent and discriminant validity tests when employing Average Variance Extracted (AVE). The square root of the latent variables must be larger than the correlation between latent variables in the AVE. The result demonstrates the Factor Loading and AVE computations, respectively. All Factor Loading values exceed 0.7, and all AVE values above 0.5 , indicating that all indicators and variables are valid. 


\section{Discriminant Validity}

Cross-loading of the indicator, the Fornell \& Larcker criterion can be used to verify discriminant validity. When considering cross-loading, the factor loading indications on the assigned construct must be bigger than all other loading indicators, with the factor loading cut-off value being greater than 0.70. (Ab Hamid, et al., 2017). The result demonstrates the Fornell Larcker Criterion and Cross Loading computation. In Fornell Larcker Criterion all the value of the correlation of a variable with the variable itself is greater than the relationship with other variables which means the data is valid. In Cross Loadings calculation the correlation values of indicators toward its variable is greater than correlation values toward other variables thus the data considered as valid.

\section{Reliability Test}

Table 2: Reliability Test

\begin{tabular}{llll}
\hline Variables & Cronbach Alpha & $\begin{array}{l}\text { Composite } \\
\text { Reliability }\end{array}$ & rho_A \\
\hline $\begin{array}{l}\text { Green Brand Affect } \\
(\text { GB })\end{array}$ & 0.849 & 0.909 & 0.850 \\
$\begin{array}{l}\text { Green Brand } \\
\text { Association (GAS) }\end{array}$ & 0.842 & 0.905 & 0.845 \\
$\begin{array}{l}\text { Green Brand Attitude } \\
\text { (GAT) }\end{array}$ & 0.836 & 0.902 & 0.838 \\
$\begin{array}{l}\text { Green Purchase } \\
\text { Intention (GPI) }\end{array}$ & 0.867 & 0.904 & 0.869 \\
\hline
\end{tabular}

As we can see on Table 2 that shows Cronbach alpha and composite reliability, all of the values are above 0.7 thus the datas can be said as reliable.

\section{Structural Part Significance}

After completing the previous steps, the researcher analyzes the inner and outer models using bootstrapping, a SmartPLS process, to determine the hypothesis association. The researcher can assess whether the hypothesis is accepted or rejected based on the results. There are four variables and 14 indicators in the present model. Three indicators construct the Green Brand Affect. Three indicators construct the Green Brand Association. Three indications construct Green Brand Attitude. There are five indications that construct Green Purchase Intention.

Path coefficients, coefficient of determination (R2), and cross-validated redundancy are some of the criteria used to assess model quality (Q2). T-values, which must be larger than or equal to 1.96, reflect the significance of the model's link.

Table 3: Path Coefficients

\begin{tabular}{llll}
\hline & Original Sample & $\begin{array}{l}\text { T Statistic } \\
(\mid \mathbf{O} / \text { STDEV } \mid)\end{array}$ & P Values \\
\hline $\begin{array}{l}\text { Green Brand Affect } \\
\text { (GB) -> Green Brand } \\
\text { Association (GAS) }\end{array}$ & 0.612 & 10.379 & 0.000 \\
\hline
\end{tabular}




\begin{tabular}{llll}
\hline $\begin{array}{l}\text { Green Brand Affect } \\
\text { (GB) -> Grand Brand }\end{array}$ & 0.518 & 8.204 & 0.000 \\
Attitude (GAT) & & & \\
$\begin{array}{l}\text { Grand Brand Affect } \\
\text { (GB) -> Green }\end{array}$ & 0.222 & 2.619 & 0.009 \\
$\begin{array}{l}\text { Purchase Intention } \\
\text { (GPI) }\end{array}$ & & \\
$\begin{array}{l}\text { Green Brand } \\
\text { Association (GAS) -> } \\
\text { Green Brand Attitude } \\
\text { (GAT) }\end{array}$ & 0.297 & 4.505 & 0.000 \\
$\begin{array}{l}\text { Green Brand } \\
\text { Association (GAS) -> } \\
\text { Green Purchase }\end{array}$ & 0.047 & & \\
Intention (GPI) & & 0.742 & 0.458 \\
$\begin{array}{l}\text { Green Brand Attitude } \\
\text { (GAT) -> Green }\end{array}$ & 0.560 & & \\
$\begin{array}{l}\text { Purchase Intention } \\
\text { (GPI) }\end{array}$ & & 9.159 & \\
\hline
\end{tabular}

From Table 3 we can see all of the original sample values are above 1 which indicates that all of the relationship is positive. $\mathrm{R}$ square is the coefficient of determination between the dependent and independent variables, which accounts for the effects of the other independent variables (Malhotra, 2016). In other words, the $\mathrm{R}$ square is beneficial for forecasting and determining how much influence the independent variable has on the dependent variable at the same time.

The result demonstrate that Green Brand Affect as independent variable influence Green Brand Association as much as $37.2 \%$ and influence Green Brand Attitude as much as $54.1 \%$, moreover Green Purchase Intention is influences by Green Brand Affect, Green Brand Association, and Green Brand Attitude as much as 57.8\%.

The Q2 value ranges from $0.02,0.15$, and 0.35 , with small, medium, and strong prediction accuracy (Hair, J. F.,et al, 2013). As a result, the values obtained for behavior intention and use behavior are $0.278,0.400$, and 0.374 respectively, indicating a medium to high level of predictive accuracy. According to Wong (2013), the goodness of fit value can be calculated after considering R square and $\mathrm{Q}$ square by taking the average square root of R2 and multiplying it by the average value of Q2. The value must be more than 0.1 .

Table 4: Goodness of Fit

\begin{tabular}{lll}
\hline & R square & Q square \\
\hline $\begin{array}{l}\text { Green Brand Association } \\
\text { (GAS) }\end{array}$ & 0.372 & 0.278 \\
Green Brand Attitude (GAT) & 0.541 & 0.400 \\
Green Purchase Intention (GPI) & 0.578 & 0.374 \\
Average & 0.497 & 0.351 \\
GoF & 0.247 & \\
\hline
\end{tabular}


According to Table 4, the goodness of fit value is 0.247 (> 0.1$)$ which indicates that the proposed model can explain the findings.

\section{Hypothesis Testing}

In this section, the researcher will give the PLS calculation to explain the hypothesis testing outcome, as well as the significance suggested by T-values and the inner model path coefficient. Table 5 shows the results of the hypothesis testing.

Table 5: Hypothesis Testing Result

\begin{tabular}{|c|c|c|c|c|}
\hline Hypothesis & Structural Path & $\begin{array}{l}\text { T Statistic } \\
(|\mathrm{O} / \mathrm{STDEV}|)\end{array}$ & P Values & Result \\
\hline H1 & $\begin{array}{l}\text { Green Brand } \\
\text { Affect (GB) -> } \\
\text { Green Brand } \\
\text { Association } \\
\text { (GAS) }\end{array}$ & 10.379 & 0.000 & Accepted \\
\hline $\mathrm{H} 2$ & $\begin{array}{l}\text { Green Brand } \\
\text { Affect (GB) -> } \\
\text { Grand Brand } \\
\text { Attitude (GAT) }\end{array}$ & 8.204 & 0.000 & Accepted \\
\hline H3 & $\begin{array}{l}\text { Grand Brand } \\
\text { Affect (GB) -> } \\
\text { Green Purchase } \\
\text { Intention (GPI) }\end{array}$ & 2.619 & 0.009 & Accepted \\
\hline $\mathrm{H} 4$ & $\begin{array}{l}\text { Green Brand } \\
\text { Association } \\
\text { (GAS) -> Green } \\
\text { Brand Attitude } \\
\text { (GAT) }\end{array}$ & 4.505 & 0.000 & Accepted \\
\hline H5 & $\begin{array}{l}\text { Green Brand } \\
\text { Association } \\
\text { (GAS) -> Green } \\
\text { Purchase } \\
\text { Intention (GPI) }\end{array}$ & 0.742 & 0.458 & Rejected \\
\hline H6 & $\begin{array}{l}\text { Green Brand } \\
\text { Attitude (GAT) -> } \\
\text { Green Purchase } \\
\text { Intention (GPI) }\end{array}$ & 9.159 & 0.000 & Accepted \\
\hline
\end{tabular}

\section{H1. Green Brand Affect positively influences Green Brand Association}

Hypothesis 1 indicated that green brand affect and green brand association have a significant positive relationship. Hypothesis 1 is supported based on the data in Table 5 since the t-value is greater than 1.96, which equals 10.379 at a significance level of 0.05 . (5 percent ). This suggests that there is a strong relationship between green brand affect and green brand association. 


\section{H2. Green Brand Affect positively influences Green Brand Attitude}

Hypothesis 2 indicated that green brand affect and green brand attitude have a significant positive relationship. Hypothesis 2 is supported based on the data in Table 5 since the t-value is greater than 1.96, which equals 8.204 at a significance level of 0.05 . (5 percent ). This suggests that there is a strong relationship between green brand affect and green brand attitude.

\section{H3. Green Brand Affect positively influences Green Purchase Intention}

Hypothesis 3 indicated that green brand affect and green purchase intention have a significant positive relationship. Hypothesis 3 is supported based on the data in Table 5 since the $\mathrm{t}$-value is greater than 1.96, which equals 2.619 at a significance level of 0.05 . (5 percent ). This suggests that there is a strong relationship between green brand affect and green purchase intention.

\section{H4. Green Brand Association positively influences Green Brand Attitude}

Hypothesis 4 indicated that green brand association and green brand attitude have a significant positive relationship. Hypothesis 4 is supported based on the data in Table 5 since the t-value is greater than 1.96, which equals 4.505 at a significance level of 0.05 . ( 5 percent ). This suggests that there is a strong relationship between green brand association and green brand attitude.

\section{H5. Green Brand Association positively influences Green Purchase Intention}

Hypothesis 5 indicated that green brand association and green purchase intention does not have significant relationship. Hypothesis 5 is not supported based on the data in Table 5 since the t-value is lower than 1.96, which equals 0.742 at a significance level of 0.05 . (5 percent ). This suggests that there is no correlation between green brand association and green purchase intention.

\section{H6. Green Brand Attitude positively influences Green Purchase Intention}

Hypothesis 6 indicated that green brand attitude and green purchase intention have a significant positive relationship. Hypothesis 6 is supported based on the data in Table 5 since the t-value is greater than 1.96, which equals 9.159 at a significance level of 0.05 . (5 percent ). This suggests that there is a strong relationship between green brand attitude and green purchase intention.

\section{Mediating Result}

The mediating test is used to determine the impact of mediating variables. Its goal is to use mediating variables to evaluate the dependent and independent variables. The Green Brand Association did not pass the third requirement, so it was considered as not mediating. The direct effect of green brand association to green purchase intention is not significant (p-value $<0.05$ ). Green Brand Affect significantly influences Green Purchase Intention ( $p$-value > 0.05) and Green Brand Attitude also significantly influences Green Purchase Intention. So, it means green brand attitude is a partial mediation variable.

\section{Discussion}

\section{Green Brand Affect positively influences Green Brand Association}

From the result the researcher can see that green brand affects have a positive influence towards green brand association. Thus, hypothesis one is accepted. It means that when consumers have a positive feeling towards a brand it influences the amount of consumer's awareness towards the green brand as well as how they feel and judge about them. This result is aligned with the research findings by Chen, 
et al. (2020). The indicators that were asked of the respondents for the green brand affect variable showed that the respondents felt that the green skincare brand caused positive feelings that affected the favorability and strength of the brand in the eyes of consumers, in line with Chen, et al. (2020) which states that the green brand association can be characterized by three aspects, namely strength, favorability, and uniqueness.

\section{Green Brand Affect positively influences Green Brand Attitude}

The relationship between green brand affect and green brand attitude is positively related which means that hypothesis is supported. It can be concluded that when consumers have a good feeling towards a green brand, they are most likely to have a positive appraisal towards the overall performance of a green brand. This result is aligned with the prior research (Chen, et al., 2020).

\section{Green Brand Affect positively influences Green Purchase Intention}

According to the hypothesis test result, the green brand affect does have a positive influence on green purchase intention. So it can be said that hypothesis is accepted. It can be assumed that when consumers of green products elicit a positive response can influence consumer purchase intention.

\section{Green Brand Association positively influences Green Brand Attitude}

Based on the result of the hypothesis test, green brand associations have a positive influence on green brand attitude. Positive thoughts have a positive impact on the formation of a positive brand attitude, whereas negative thoughts have the opposite effect (Olson, et al., 1982) and feelings and emotional responses can be evoked by brand associations (Sujan, et al., 1993; Schindler and Holbrook, 2003; Escalas, 2004) means that the hypothesis is supported.

\section{Green Brand Association does not have any influences on Green Purchase Intention}

The result of the hypothesis is rejected. Green brand association does not influence green purchase intention, this is a new finding since there is no prior study that studies this in Indonesia. This explains that when consumers have knowledge about a green brand it does not mean it will generate intention to buy. This result is contradictory with the prior study result.

\section{Green Brand Attitude positively influences Green Purchase Intention}

The relationship between green brand attitude and green purchase intention is positive which means that the hypothesis is accepted. We can assume that how consumers perceive the green brand's overall performance is influencing their intention to buy a green brand. The result is aligned with prior studies that said attitudes play a significant role in determining consumers' purchasing intentions (Yi, 1990; Goldsmith, et al., 2000).

\section{Conclusion}

The impact of a green brand is a critical market determinant. Prior study has been inconclusive as to how green buying intentions may be improved and contained to a significant degree in the current era of sustainable consumerism. As a result, we develop a conceptual approach to green branding to encourage green purchase intentions. This study creates a research framework to investigate the impact of green brand affect on green purchasing intentions, as well as the role of green brand associations and attitude as intermediaries.

One of the objectives of this study is to identify the influence of the green brand affect towards green purchase intention. The results of this objective indicate that green brand affect can directly influence green purchase intention with t-value of 2.619 the relationship between these two variables is also positive with original sample value of 0.222 , which is above zero. 
The second objective of this research is to identify the most significant factors influencing green purchase intention. The results of this study are that the green brand association has no effect on green purchase intention so that it fails to become a mediating variable, while green brand attitude acts as a partial mediating variable because green brand affect already has a direct significant relationship with green purchase intention. Therefore, the most significant variable affecting green purchase intention is green brand attitude with a t-value of 0.560 .

And last, this research wants to give recommendations specifically to businesses owners that are engaged in the skin care industry in order to increase green purchase intention. The result shows that green brand affect has positive influence toward green purchase intention directly and green brand attitude partially mediated green brand affect to green purchase intention, means that if business owner wants to increase green purchase intention they need to increase green brand affect and green brand attitude. As a result, in order to encourage sustainable consumption, business owners must design a more effective green branding strategy. Because the most significant variable is green brand attitude, it is important for business owners to understand what their customers like and dislike because this might be their key driver. According to the behavioral survey of this study the highest factor the respondents consider is price for skin care products and for skin care products with environmentally friendly claims, the most important factor is environmental friendliness performance.

\section{References}

Aaker, D. (1991). Managing Brand Equity.

Ab Hamid, M. R., Sami, W., \& Mohmad Sidek, M. H. (2017). Discriminant Validity Assessment: Use of Fornell \& Larcker criterion versus HTMT Criterion. Journal of Physics: Conference Series, 890(1). https://doi.org/10.1088/1742-6596/890/1/012163

Amindoni, A., \& Adzkia, A. (2021). Banjir dan bencana beruntun di tengah cuaca ekstrem, "Menurut pemerintah itu anomali cuaca, kami menyebutnya krisis iklim." BBC Indonesia. https://www.bbc.com/indonesia/indonesia-56007558

BERNARD, R. (2006). Research Methods in Anthropology Qualitative and Quantitative Approaches, Sixth Edition.

Chang, H. H., \& Chen, S. W. (2008). The impact of online store environment cues on purchase intention: Trust and perceived risk as a mediator. Online Information Review, 32(6), 818-841. https://doi.org/10.1108/14684520810923953

Chaudhuri, A., \& Holbrook, M. B. (2001). The chain of effects from brand trust and brand affect to brand performance: The role of brand loyalty. Journal of Marketing, 65(2), 81-93. https://doi.org/10.1509/jmkg.65.2.81.18255

Chen, Y. S., \& Chang, C. H. (2012). Enhance green purchase intentions: The roles of green perceived value, green perceived risk, and green trust. Management Decision, 50(3), 502-520. https://doi.org/10.1108/00251741211216250

Chen, Y. S., Chang, T. W., Li, H. X., \& Chen, Y. R. (2020). The influence of green brand affect on green purchase intentions: The mediation effects of green brand associations and green brand attitude. International Journal of Environmental Research and Public Health, 17(11), 1-17. https://doi.org/10.3390/ijerph17114089

Chen, Y. S., Hung, S. T., Wang, T. Y., Huang, A. F., \& Liao, Y. W. (2017). The influence of excessive product packaging on green brand attachment: The mediation roles of green brand attitude and green brand image. Sustainability (Switzerland), 9(4). https://doi.org/10.3390/su9040654

Dewi, R. (2021). Catatan BNPB: Ada 263 Bencana Sepanjang Januari 2021. https://www.kompas.com/tren/read/2021/02/01/102800165/catatan-bnpb--ada-263-bencanasepanjang-januari-2021?page $=$ all

Eagle, A. ., \& Chaiken, S. (1995). Book Review. Psychology \& Marketing, 12(August), 80948.

Erevelles, S. (1998). The Role of Affect in Marketing. Journal of Business Research, 42(3), 199-215. https://doi.org/10.1016/S0148-2963(97)00118-5

Escalas, J. E. (2004). Imagine yourself in the product: Mental simulation, narrative transportation, and 

DOI: https://doi.org/10.47405/mjssh.v6i8.965
persuasion.
Journal
of
Advertising,
$33(2)$,
$37-48$.

https://doi.org/10.1080/00913367.2004.10639163

Etikan, I. (2016). Comparison of Convenience Sampling and Purposive Sampling. American Journal of Theoretical and Applied Statistics, 5(1), 1. https://doi.org/10.11648/j.ajtas.20160501.11

Europa. (2020). Causes of Climate Change. https://ec.europa.eu/clima/change/causes_en

Fornell, C., \& Bookstein, F. L. (2012). Structural to Consumer. Journal of Marketin Research, 19(4), $440-452$.

Gobe, M. (2009). Emotional Branding. Allworth Press.

Goldsmith, R. E., Lafferty, B. A., \& Newell, S. J. (2000). The impact of corporate credibility and celebrity credibility on consumer reaction to advertisements and brands. Journal of Advertising, 29(3), 43-54. https://doi.org/10.1080/00913367.2000.10673616

Hair, J. F., Hult, G. T. M., Ringle, C. M., \& Sarstedt, M. (2013). A Primer on Partial Least Squares Structural Equation Modeling (PLS-SEM). Thousand Oaks. Sage, 165.

Hair, J. F., Ringle, C. M., \& Sarstedt, M. (2011). PLS-SEM: Indeed a silver bullet. Journal of Marketing Theory and Practice, 19(2), 139-152. https://doi.org/10.2753/MTP1069-6679190202

Hoyer, W. D., \& Maclnnis, D. J. (1997). Consumer Behavior. Boston Houghton Mifflin.

Keller, K., \& Aaker, D. (1990). Consumer Evaluations of Brand Extensions. Journal of Marketing, 54(1), 27-41.

LAKE, L. (2021). Why Branding Is Important in Marketing. https://www.thebalancesmb.com/why-isbranding-important-when-it-comes-to-your-marketing-2294845

Malhotra, N. K., Nunan, D., \& Birks, D. F. (2016). Marketing research. In The Marketing Book: Seventh Edition. https://doi.org/10.4324/9781315890005

Matzler, K., Bidmon, S., \& Grabner-Kräuter, S. (2006). Individual determinants of brand affect: The role of the personality traits of extraversion and openness to experience. Journal of Product and Brand Management, 15(7), 427-434. https://doi.org/10.1108/10610420610712801

McWilliam, G. (1993). Managing brand equity: Capitalizing on the value of a brand name. International Journal of Research in Marketing, 10(1), 105. https://doi.org/10.1016/01678116(93)90037-y

Mostafa, M. M. (2006). Journal of International Consumer Marketing Antecedents of Egyptian Consumers ' Green Purchase Intentions Antecedents of Egyptian Consumers' Green Purchase Intentions : A Hierarchical Multivariate. Journal of International Consumer Marketing, July 2013, 97-126. https://doi.org/10.1300/J046v19n02

Olson, J. C., Toy, D. R., \& Dover, P. A. (1982). Do Cognitive Responses Mediate the Effects of Advertising Content on Cognitive Structure? Journal of Consumer Research, 9(3), 245. https://doi.org/10.1086/208921

Pawle, J., \& Cooper, P. (2006). Measuring Emotion-Lovemarks, The Future Beyond Brands. $10.2501 / \mathrm{S} 0021849906060053$

Praxmarer, S., \& Gierl, H. (2009). The effects of positive and negative ad-evoked associations on brand attitude. Asia Pacific Journal of Marketing and Logistics, 21(4), 507-520. https://doi.org/10.1108/13555850910997562

Roston, E. (2021). This chart shows how global temperatures have risen since 1950. World Economic Forum. https://www.weforum.org/agenda/2021/01/climate-change-global-warming-carbondioxide-emissions-science/

Sallam, M. A. A., \& Wahid, N. A. (2012). Endorser Credibility Effects on Yemeni Male Consumer's Attitudes towards Advertising, Brand Attitude and Purchase Intention: The Mediating Role of Attitude toward Brand. International Business Research, 5(4), 55-66. https://doi.org/10.5539/ibr.v5n4p55

Sauro, J. (2010). Should You Use 5 Or 7 Point Scales? https://measuringu.com/scale-points/

Schindler, R. M., \& Holbrook, M. B. (2003). Nostalgia for Early Experience as a Determinant of Consumer Preferences. Psychology and Marketing, 20(4), 275-302. https://doi.org/10.1002/mar.10074

Sujan, M., Bettman, J. R., \& Baumgartner, H. (1993). Influencing Consumer Judgments Using Autobiographical Memories: A Self-Referencing Perspective. Journal of Marketing Research, 30(4), 422. https://doi.org/10.2307/3172688

UNEP. (2020). Report: Consumers and business concerned about plastic waste but expect governments to do more. https://www.unep.org/news-and-stories/press-release/report- 
DOI: https://doi.org/10.47405/mjssh.v6i8.965

consumers-and-business-concerned-about-plastic-waste-expect

Wong, K. K. K.-K. (2013). 28/05 - Partial Least Squares Structural Equation Modeling (PLS-SEM) Techniques Using SmartPLS. Marketing Bulletin, 24(1), 1-32. http://marketingbulletin.massey.ac.nz/v24/mb_v24_t1_wong.pdf\%5Cnhttp://www.researchgate.net/profile/Ken_ Wong10/publication/268449353_Partial_Least_Squares_Structural_Equation_Modeling_(PLSSEM)_Techniques_Using_SmartPLS/links/54773b1b0cf293e2da25e3f3.pdf

WWF. (2019). Plastic waste and climate change - what's the connection? https://www.wwf.org.au/news/blogs/plastic-waste-and-climate-change-whats-theconnection\#gs.tkleo8

Yi, Y. (1990). Cognitive and affective priming effects of the context for print advertisements. Journal of Advertising, 19(2), 40-48. https://doi.org/10.1080/00913367.1990.10673186

ZAP Beauty Clinic \& Markplus Inc. (2020). ZAP Beauty Index 2020. Mark Plus Inc, 1-36.

Zhang, E. M. (2010). Understanding the Acceptance of Mobile SMS Advertising among Young Chinese Consumers. Psychology \& Marketing, 30(6), 461-469. https://doi.org/10.1002/mar 